Waters, Leslie M.. "The Hungarians of Slovakia in 1938. New York: Columbia University Press, East European Monographs. 353 pp." Hungarian Cultural Studies. e-Journal of the American Hungarian Educators Association, Volume 9 (2016): http://ahea.pitt.edu DOI: 10.5195/ahea.2016.244

\title{
Simon, Attila. 2013. The Hungarians of Slovakia in 1938. New York: Columbia University Press, East European Monographs. 353 pp.
}

\section{Reviewed by Leslie M. Waters, Randolph-Macon College}

In his foreword to The Hungarians of Slovakia in 1938, Attila Simon lays out three tasks he hopes to fulfill in this monograph: to give a balanced account of the religiously and politically diverse Hungarian minority of Czechoslovakia during the interwar period that highlights the limitations and opportunities encountered by this community in the democratic but nationalizing state; to articulate the many differences between the Sudeten German and Slovak Hungarian communities during the critical year of 1938; and to "dispute the accusation that [in 1938] the Hungarians in Slovakia betrayed Czechoslovakia" (xviii). This list should give readers some insight into the polemical historiography existing on this topic, which for decades has tended to emphasize the Hungarian community's complicity with the Sudeten Germans in destroying the Czechoslovak Republic, in part as a way to justify the state's post-World War II persecution of Slovak Hungarians. Simon mostly succeeds in debunking this accusation, showing instead that Hungarians in Czechoslovakia took a conservative approach to territorial revision, including promising not to undermine the state and vowing to pursue legal means to rectify their grievances.

The Hungarians of Slovakia in 1938 is a translation of Simon's 2010 Egy rövid esztendö krónikája: A szlovákiai magyarok 1938-ban (Somorja: Fórum Kisebbségkutató Intézet; fully available at: http://mek.oszk.hu/08900/08988/08988.pdf), closely following the structure of the original monograph. Its first, very lengthy, chapter provides a survey of the twenty-year history of the Slovak Hungarian community from the breakup of historic Hungary in 1918 up to 1938, the year in which southern Slovakia was re-annexed to Hungary and the majority of Slovak Hungarians again became part of the Hungarian State. Simon convincingly shows that Slovak Hungarians had taken advantage of the democratic institutions of the Czechoslovak State by forming a number of political parties and social institutions; yet, they also experienced significant hardships such as underrepresentation in government positions, a dearth of Hungarian-language schools, and an unresolved citizenship status for thousands of individuals. Simon then goes on to discuss the major events of 1938 in Czechoslovakia as they concerned the Hungarian community, with chapters on the twentieth-anniversary celebrations of the Czechoslovak State, the 1938 local elections, the debates surrounding the Czechoslovak Nationality Statute, the Munich Agreement, and the Komárom/Komárno negotiations of October 1938 on the future border between Hungary and Czechoslovakia.

Simon is a careful researcher who is at his best when combining a wide variety of sources to reconstruct historical events that have been left obscured by incomplete archival records. His expertise is convincingly demonstrated by his analysis of the local elections of 1938 in Slovakia, the results of which were never published by the Czechoslovak government that was reluctant to publicly acknowledge the strong showing of minority political parties. By painstakingly comparing fragmentary archival sources and contemporary reports in local and regional newspapers, Simon shows that the new United Hungarian Party, formed in 1936, won the 1938

$($ (c) $)$ EY

ULIS D-Serk
New articles in this journal are licensed under a Creative Commons Attribution 4.0 International License.

This journal is published by the University Library System of the University of Pittsburgh as part of its D-Scribe Digital Publishing Program and is cosponsored by the University of Pittsburgh Press 
Waters, Leslie M. "The Hungarians of Slovakia in 1938. New York: Columbia University Press, East European Monographs. 353 pp." Hungarian Cultural Studies. e-Journal of the American Hungarian Educators Association, Volume 9 (2016): http://ahea.pitt.edu DOI: 10.5195/ahea.2016.244

elections in most Hungarian-majority settlements, poaching voters from the Communist and Social Democratic Parties that had traditionally done quite well in southern Slovakia. Thus, by the year of the Czechoslovak crisis, 1938, the Hungarian minority had already successfully formed a consolidated voting bloc through the United Hungarian Party.

Simon also brings to light a handful of minor border incidents that occurred in October 1938 that reveal the volatile after-effects of the Munich Agreement that ceded Czechoslovak territory to Germany in the Sudetenland on the country's western boundary. In one case, an overzealous Hungarian border-guard commander launched an offensive into Czechoslovak territory at Kacagópuszta (Orávka), without authorization, in the hopes of occupying southern Slovakia by force instead of waiting for negotiators to redraw the border. Czechoslovak forces killed or captured several Hungarian soldiers during the attack, and the rest retreated back across the border. This incident, which, remarkably (given the incredibly tense atmosphere of late 1938), escalated no further, exemplifies the plurality of opinions on how to approach the question of border revision. Rogue border-guard commanders, Hungarian military leaders, Hungarian government ministers, and representatives of the Hungarian minority in Slovakia all had different conceptualizations of how and when border changes should occur. Simon demonstrates that of all these actors, those most directly affected by territorial revision, the Hungarians of Czechoslovakia, had the least power. Although by 1938 the Hungarian minority had a relatively united political party that claimed, with considerable legitimacy given the elections results, to represent the Hungarian community's interests, in October 1938 their leaders were explicitly barred from participating in territorial negotiations by both the Hungarian and the Czechoslovak governmental delegations.

In the literature on minority Hungarian communities, Transylvanian Hungarians receive the lion's share of attention, but The Hungarians of Slovakia in 1938 reminds readers that Czechoslovakia's Hungarians, while less researched, may have been an even more dynamic minority community given the opportunities afforded to them under Czechoslovak democracy to form active political parties and social organizations. Simon shows that by 1938 Czechoslovak Hungarians could pinpoint important differences between themselves and their co-ethnics in Hungary. Their experience living as a minority community and their experience with democracy created important dividing lines between the two communities, which would cause conflicts between these two groups following the re-annexation.

The history of the Hungarians of Czechoslovakia in the year 1938 prompts a number of interesting historical questions: What do borders really mean for everyday people? How does a minority community respond to a breakdown in the legitimacy of the state? How did people who had lived in a functioning democracy for twenty years feel about inevitably losing certain rights and privileges for the tradeoff of returning to their "homeland"? Though these questions are brought up in The Hungarians of Slovakia in 1938, Simon does not adequately pursue what could be some very insightful lines of inquiry. Instead, he chooses to focus mainly on the refutation of the obviously flawed Czech and Slovak nationalist historiographical arguments that in 1938 the Hungarians betrayed the Czechoslovak State. Simon's decision is understandable given the weakness of the historiography on the topic, but it is also a missed opportunity, since it leaves so many more interesting questions yet unanswered. 